\title{
Management by Chaos Theory with a Case-Study from Shipping Industry
}

\author{
Alexandros M. Goulielmos'1,2 \\ ${ }^{1}$ Marine Economics, University of Piraeus, Department of Maritime Studies, Faculty of Maritime and Industrial Studies, Piraeus, \\ Greece \\ ${ }^{2}$ Shipping Department, Business College of Athens, Athens, Greece \\ Email: ag@unipi.gr,am.goulielmos@hotmail.com, agoulielmos@bca.edu.gr
}

How to cite this paper: Goulielmos, A.M. (2019) Management by Chaos Theory with a Case-Study from Shipping Industry. Modern Economy, 10, 2004-2029. https://doi.org/10.4236/me.2019.108127

Received: June 10, 2019

Accepted: August 25, 2019

Published: August 28, 2019

Copyright (C) 2019 by author(s) and Scientific Research Publishing Inc. This work is licensed under the Creative Commons Attribution International License (CC BY 4.0).

http://creativecommons.org/licenses/by/4.0/

\begin{abstract}
We presented the two faces of Management: the linear and the nonlinear. The second we named it Management by Chaos Theory, and we used the limit cycle tool to determine the order of chaos, in which companies, most probably $61 \%$ of them will face the highest order of chaos. We showed also how the technique of full Descartes' Diagrams, using changes in variables, may help managers. We presented diagrammatically how a manager can manage his/her company by visioning. We presented also a historical making-up of Linear Management since 1911 and contrasted it with nonlinear one, clarifying the terms of mission and vision. We grasped the opportunity to analyze the mission of a shipping company, and use its 12-year activity as a case study. This company found itself in high order chaos from 1996 to 2000. The paper showed how a manager could not get in a Chaos area and if in it, how to get out.
\end{abstract}

\section{Keywords}

Vision, Mission, Limit Cycle, Case-Study of Eletson Shipping Company, Order of Chaos, Linear Management History

\section{Introduction}

Can chaos Theory be used to manage companies given that Chaos, justifiably, has confused managers? For them chaos means disorder. Indeed, managers' perception is that chaos is a state of turmoil, confusion, and lack of order. Chaos, moreover, is considered as the amorphous lifeless void from which earth emerged at creation (Hesiod, $8^{\text {th }}$ c. B.C.), depriving God from one of his most important works: The creation of the Universe.

The contemporary opinion is, however, different: chaos has structure, high 
complexity, and many patterns, like the weather and the waterfalls. It is deterministic, with laws of organizing, it appears random, but it is not. The only weak point is that chaos's ability to forecast long periods is diminishing with time (Lyapunov exponent). Chaos is expressed by fractal (non-integer) mathematics, which dominates par excellence in Nature [1] and in the structure of the human body. The word fractal comes from the Latin verb "frangere", meaning "to break". Fractal means a fraction of a whole. Readers unfamiliar with chaos theory may read the scientific book of a journalist [2].

The Greek mathematician Euclid ( $3^{\text {rd }}$ c. B.C.) disorientated his colleagues from fractal geometry, as he dealt exclusively with solid bodies and shapes (e.g. the circle $=\mathrm{a}$ harmonic divine shape) expressed by integers. Moreover, all have been brought-up in linear sciences by education. Linearity is based on the principle that a $10 \%$ cause creates exactly an equal result. Real life has shown that this is not true. Life is mostly, some argue 95\%, nonlinear.

Apart from the puzzle of mathematicians, bankers and investors were, and still are, perhaps in a lesser degree, disappointed by the inaccurate predictions provided by using traditional tools embedded in linear philosophy (i.e. normal distribution) [3].

In addition, four at least severe economic crises (depressions) repeated themselves undisturbed in the last 120 years or so (Figure 1). This confirmed the inability of economists to pre-act to a forthcoming economic disaster, even if they saw it coming, as in 2007 [4].

As shown, the first major economic crisis was the one in 1929 (04/09)-1933-1936, known also as the Great Depression, with the USA stock market crash (29/10/1929; called "black Tuesday"). International trade fell by more than $50 \%$. Unemployment in USA rose to $25 \%$ and $33 \%$ elsewhere. Heavy industry declined sharply, construction stopped and crop prices fell by $60 \%$, while mining and logging suffered.

In Black Monday (19/10/1987) stock markets round the globe crashed starting in Hong Kong $(-45.5 \%)$, Europe and USA $(-23 \%)$ and elsewhere. DJIA fell by 508 points to $\sim 1739(-23 \%)$. Interesting is that the DJIA departed from its mean $22 \sigma$ ! It is recognized as a sudden drop in stock prices, which turned into a rout by a wall of insurance options crashing down on the market.

The dot-com bubble or crash (2001) attributed to speculation (mainly in USA) for a rather long period (1994-2000) using as a platform the internet. NASDAQ after March 2000 crashed, while many companies failed and closed down. Some companies' stocks fell by $86 \%$.

The Global financial crisis in end-2008 is due to various market and regulatory failures and macro-economic environment of cheap credit with new models of securitization ${ }^{1}$ and relaxed international capital flows. It started in USA,

\footnotetext{
${ }^{1}$ This is a method where a claim against somebody, say from a loan, can be sold to another bank in a certain \% of its nominal value being a tradeable title or security. In Greece, these loans are called "red loans" (they are not served) and amount to over $€ 100 \mathrm{~b}$.
} 


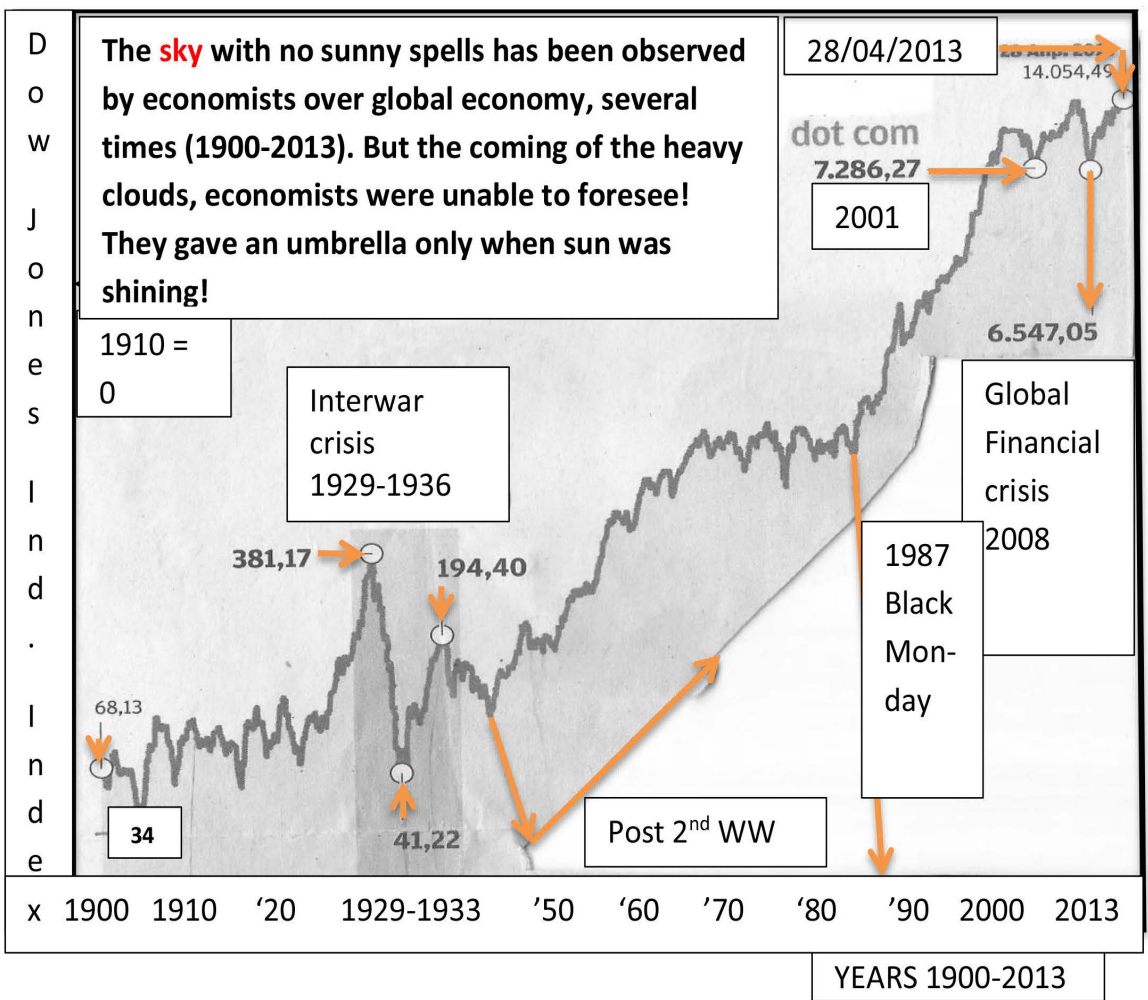

Figure 1. Heavy clouds appeared in the sky of World Economy several times (19002013).

where plethora of loans was given on house mortgages (called sub-prime) on the basis of an income from employment, which suddenly lost due to global recession. The system of securitization helped the crisis to spread to the rest of the world till 2019.

Chaos Theory caused the establishment ${ }^{2}$ of the Santa Fe Institute (SFI) (1984) for the study of Complexity Science. The City bank provided the required financial support (apropos 1987 is known for Black Monday).

The aims of the paper are: 1) to show how to manage a (tramp ${ }^{3}$ shipping) company using a tool from Chaos Theory. 2) To clarify such terms like mission, vision, goals and objectives. 3) To apply limit cycle [5] and 4) to show how to find-out companies' order of chaos.

The paper is organized in five parts. After literature review, Part I dealt with methodology and terminology. Part II, dealt with how Chaos has evolved over time (since 1886). Part III, dealt with Linear Management (since 1911). Part IV, dealt with the basic terms in management of mission and vision. Part V, dealt with a case-study from shipping industry. Finally, we conclude.

${ }^{2}$ This is a classical reaction ofscientific world to a challenge, as this happened also with econometrics in 1932. Then, Alfred Cowles III, a wealthy investor frustrated by the imprecision of what passed for financial advice, established a foundation (called Cowles Commission/Foundation latter), related to a University and a leading econometrician, to analyze market data.

${ }^{3} \mathrm{~A}$ shipping company is tramp, if its vessels travel with no standard pre-advertised itinerary, free of any schedule. 
We believe that the paper has a practical significance because for example promotes the use of computers, which have cancelled hierarchy, as chaos theory does not work with the persons in company's hierarchy, but with the persons called attractors (those having a solution to any problem). If hierarchy is not useful, then simpler organizations structures can be adopted with a view to decide fast and in good timing. The difficulty is to be able to spot the attractors in office and among crew. Moreover, if real world is nonlinear how a manager can approach business world using linear tools?

\section{Literature Review}

Morgan [6] argued that the word "organization" derives from Greek "organon", meaning instrument; so, the concept of a company is usually loaded with a mechanical significance (p. 343). Morgan coined the word imaginization to break free of any mechanical meaning, and more important to symbolize the close link between images and actions. We organize as we imaginize, he wrote. This is a creative process where the new images and ideas can create new actions (Architecture).

The literature on chaos theory as applied to management of business companies goes back to early 1990s. Stacey (1991), [7] argued that in models we show the importance of chaos theory in the practice of management. Before Stacey only two publications are recorded.

Priesmeyer [5] wrote an excellent book (p. 254) titled: "Organizations and Chaos". He argued: organizations are nonlinear systems and they should be managed using the tools provided by chaos theory (p. xiii). It is a pity that he turned his attention to other subjects thereafter.

Kellert (1993), [8] defined the theory of chaos as the qualitative study of the unstable non-periodic behavior of the nonlinear determinants of dynamic systems. Levy (1994), [9] wrote that chaos tends to be seen in almost all business systems. He used a nonlinear simulation of the chain of the international supplies, where managers underestimated their cost. Managers had to control this process and to relocate the whole system back to a stable condition.

Phelan (1995), [10] wrote that Chaos Theory provides the ability of a substantial insight in complex systems in the world of businesses. He argued that the increased ups and downs in business world and the global speeding-up of changes observed, introduce chaotic influences into the system.

Battram [11] wrote a book (p. 267) titled "navigating complexity" with sub-title: "the essential guide to complexity theory in Business and management" for Industrial Society (UK). He wrote that (p. vi) unlike traditional science, which studies simple "ideal" phenomena based on "perfect laws", which can only be applied to a very narrow range of conditions, complexity theory studies the other $95 \%$.

Chaos theory was not known in management of shipping companies till 2002, 
when I wrote a relevant paper (Goulielmos (2002) [12] $)^{4}$, which attracted the congratulations of my colleagues. In 2015, a further analysis has appeared (Goulielmos (2015) [13] $)^{5}$. Chaos theory then applied in many maritime subjects in 2004 (Goulielmos (2004) [14] $)^{6}$ like Marine Accidents (4 papers between 2002 and 2009 have appeared $\left.{ }^{7}\right)$.

Ramnswamy, K. and Youngdahl, W. [12] argued that 44\% of employees state that their leaders do not clearly communicate firm's purpose and direction.

Goulielmos [13] presented the two faces of management, i.e. linear and nonlinear, and argued that linear management provides just a list of strategies with 22 versions, which do not help much shipping managers.

Goulielmos [14] argued that turbulence is an extreme economic phenomenon caused by forces, which should have a certain degree of intensity/energy, but they exhibit always chaotic behavior.

\section{Part I: Methodology and Terminology}

An Limit Cycle-LC emerges when points in a phase space are attracted by a circle. Moreover, a LC has also attractor (Figure 2).

The circle has a period $\mathrm{T}$ (not specified), which is the number of repetitions for a full round of motion. This is the 2 nd more complicated attractor after point one attractor. Limit cycles are distinguished by their period; in management we study those with 1 to 8 periods [5]. The $1^{\text {st }}$ limit cycle is with period ${ }^{8} 1$; let one variable be sales (the independent) and the other be profits (the dependent). From now on we work with changes in variables which we plot. The plot of the $1^{\text {st }}$ limit cycle trajectory is a single dot.

If the two variables are not constant in their changes, but one is constant and the other changes, then the limit cycle is in period 2; if plotted will give a straight line either horizontal or vertical. There is a possibility to plot a straight line rising from left down to right up if profits and sales oscillate proportionately. For period 4 and 8 limit cycle we abandon the one-quadrant Cartesian diagrams we mentioned so far and adopt the 4-quadrants one. Figure 3 is an 8 -period high order chaos.

A more complex limit cycle is the one belonging to USA's Company "Thiokol Corporation"-(TKC) (Figure 3 ) in NYSE.

The new element in the above figure is that we plot in axes changes only in the variables. Also we have to plot the trajectories from each pair of variables to next pair, starting from past to present; for a simpler exposition points are not indicated by their distances from each axis but their common point is connected by ${ }^{4}$ Complexity theory applied to Management of shipping companies, Maritime Policy \& Management, Vol. 29, 4, pp. 375-391.

${ }^{5}$ Archives of Business Research, Vol. 3, 2, Feb. 2015. Titled: "how complexity and chaos theory reformed management".

${ }^{6} \mathrm{~A}$ treatise of randomness tested also in Marine accidents, Disaster Prevention and Management, Vol. 13, 3, pp. 208-217.

${ }^{7}$ Disaster Prevention and Management, Vol. 11, 14 and 18

${ }^{8}$ Let sales be: $100 ; 110 ; 120 ; 110 ; 100 ; 110 ; 120 ; 110 ; 120 ; 110$; and 100 ; rise or fall by 10 units. Let profits be: $100 ; 110 ; 100 ; 110 ; 100 ; 110 ; 100 ; 110 ; 100$; the same pattern as sales. 


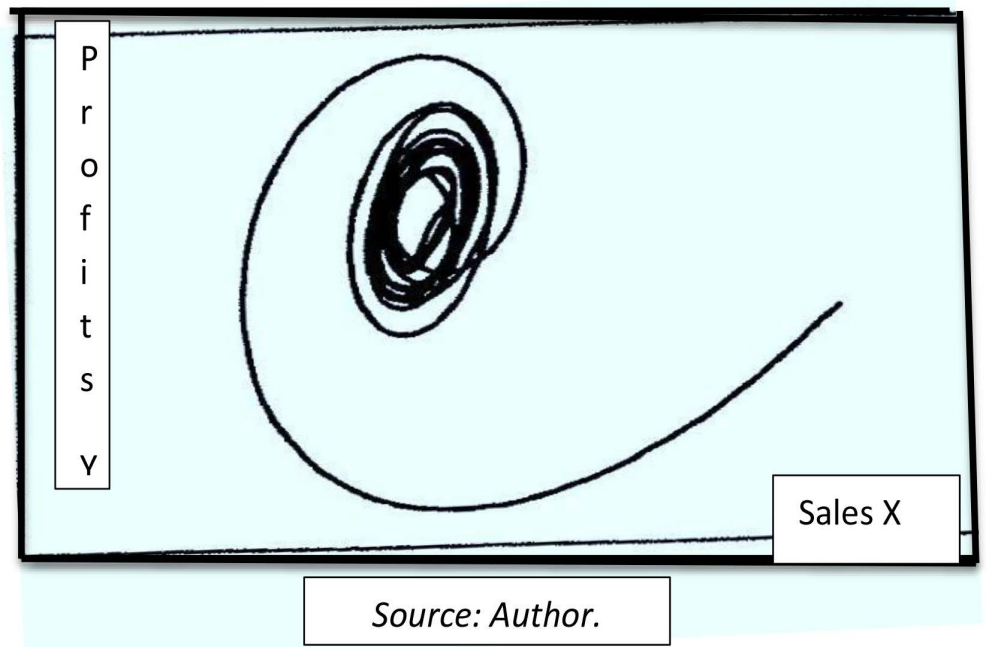

Figure 2. The limit cycle attractor.

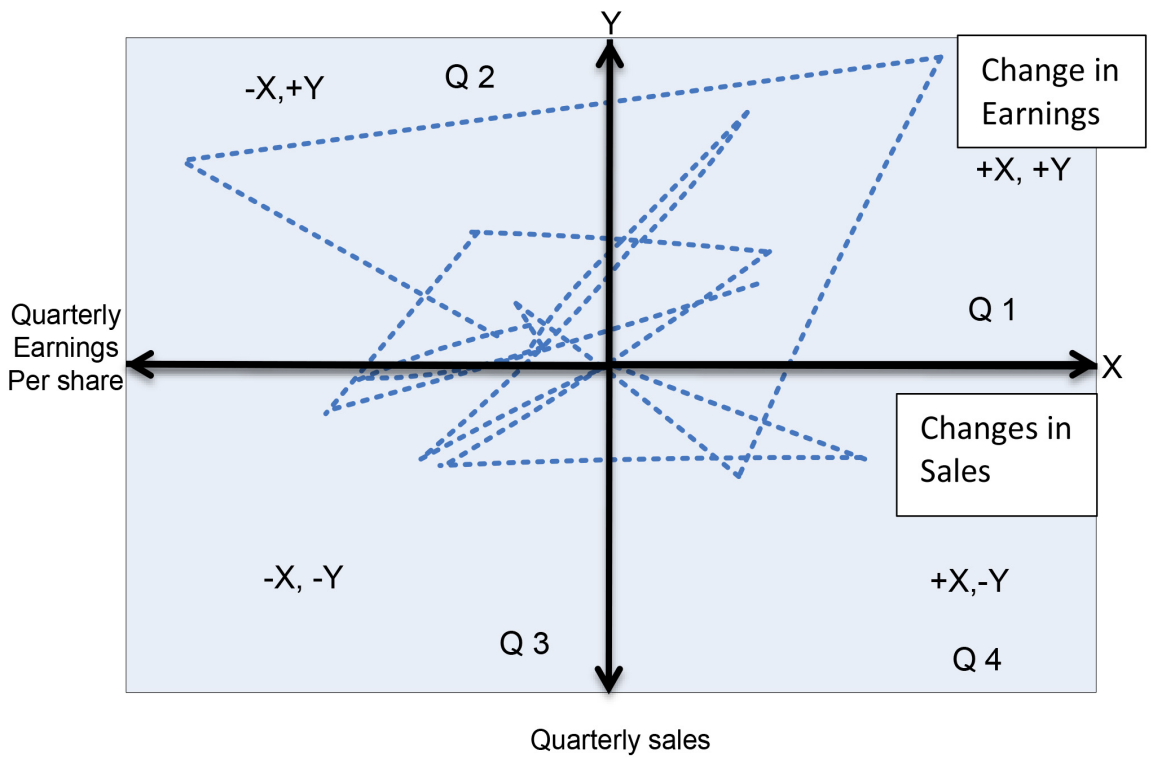

Figure 3. Thiokol Corporation: Its limit cycle. Source: Constructed by author; modified from that in Priesmeyer [5].

trajectory to the next chronological one. Within each quadrant variables either increase or fall or one increases and the other falls, as shown. The interesting part is to see what quadrants trajectories have visited ${ }^{9}$ over time. The company that its sales and its profits both increase over time are marked in quadrant Q1. This is the first best.

In horizontal axis are changes in sales, and in vertical changes in earnings (per share). This departs from tradition in which values are plotted only in Q1 quadrant. This pattern indicates an 8-period trajectory, or in other words, a chaotic attractor, (called apropos strange), and a high order of chaos. TKC's the trajec-

${ }^{9}$ Visits are recorded over time by the number of the quadrant they visited (e.g. 1, 2, 3, 4). Then the table in Priesmeyer [5] is consulted to see what it means (Appendix 1 here). 
tories visited: $1^{\text {st }}, 2^{\text {nd }}, 3^{\text {rd }}$ and $4^{\text {th }}$ quadrants (Appendix 1).

TKC had a turbulent (external) environment: in 1986, (28/01), it faulted ${ }^{10}$ (together with NASA and Marshall SF center), as a contractor, in the explosion of the shuttle orbiter Challenger, with 7 dead. TKC manufactured and assembled the "booster motors". TKC's management apparently paid no attention to the changing structural patterns bound TKC. This picture is also applicable to shipping companies after a sock from a marine accident with dead.

TKC had to reduce its order of chaos from an 8-period, where it was, to a 4-period; or in other words, TKC's trajectories had to visit: 1, 4, 2, 3 quadrants (one option out of 16, or 6\% of all combinations), and with this order. This means a rise in both sales and earnings (visitat Q1); a rise in sales, despite a fall in earnings (visitat Q4); a rise in earnings, despite a reduction in sales (visit at Q2), ending at Q3 (i.e. 1423 = period-4; a medium order of chaos).

In general, trajectories which visit frequently quadrants $2^{11}$ and $3^{12}$, head at high order chaos (period 8). In a lower order of chaos (period 4) head trajectories, which visit frequently $1^{13}$ and $4^{14}$. Given that the greater majority (61\%) of cases falls in high order chaos, we presume, this led Priesmeyer [5] to state that a high order chaos is common in businesses! Hallelujah!

\subsection{Management by Visioning}

We can use Figure 3 to show how we can implement graphically management by vision. We plot company's trajectories of the last three years, but fourth; we plot the fourth trajectory to point to future position, which company wants (vision) (Figure 4)! Theory considers more relevant for analysis the last four years in a company's activity, as being closer to the present. The above hypothetical company, in real terms, visioned a 4-period where, (i.e. 4, 3, 2, 1), by pursuing a rise in both sales and profits. Company passed from high order chaos it was (i.e. in $4,3,2,4)$ and an 8-period to a 4-period. Question: Is company's vision attainable? We reckon yes, as the previous year ( $3^{\text {rd }}$ year) company achieved a rise in profits, despite a fall in its sales (Q2), and so we believe it can vision an increase in both sales and profits.

\subsection{Further Terms from Chaos Theory}

The phase space mentioned above is mathematical, the determinants of which are the independent variables needed to determine the phase of a dynamic system (DS) at every point of time [15]. The attractor is a set of points in the phase space towards which trajectories, asymptotically, and over time, tend to for a set of initial (starting) conditions. A DS is the one that evolves over time. Thus, 10“Thiokol corporation" was a US company founded in 1929 producing rocket engines; it employed 15,000 persons (http://en.wikipedia.org/wiki/thiokol 08/06/2015). Its annual sales were $\$ 840 \mathrm{~m}$. The "Rogers Commission report" faulted Morton Thiokol for poor engineering and management.

${ }^{11}$ Fall in $\mathrm{X}$, rise in $\mathrm{Y}$.

${ }^{12}$ Fall in both $\mathrm{X}$ and $\mathrm{Y}$.

${ }^{13}$ Increases in both $\mathrm{X}$ and $\mathrm{Y}$.

${ }^{14}$ Rise in $\mathrm{X}$, fall in $\mathrm{Y}$. 


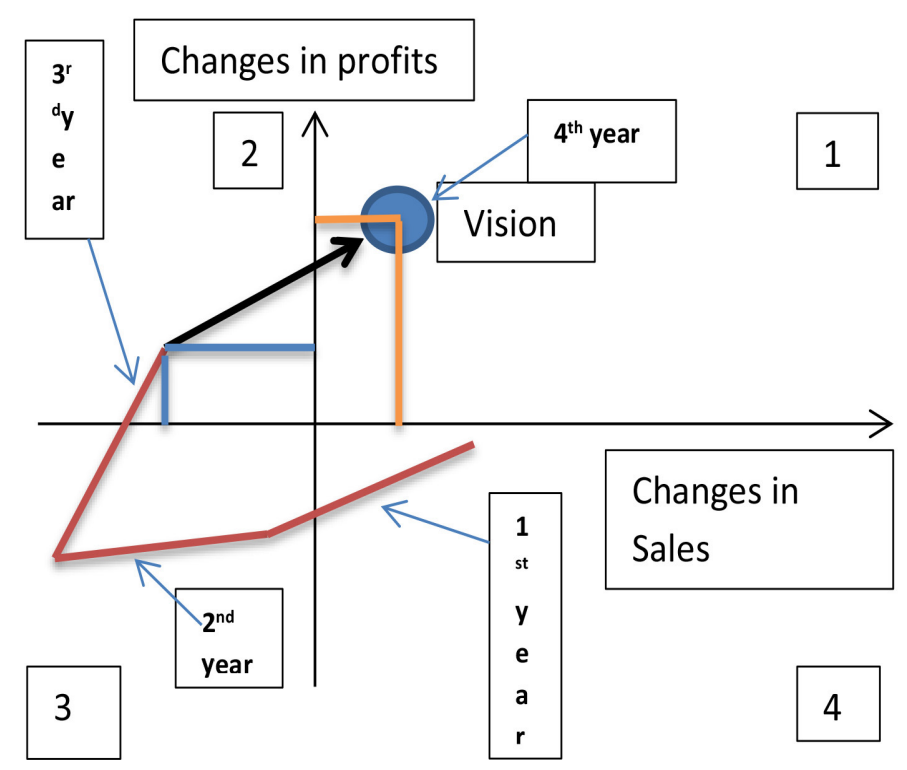

Figure 4. Using a trajectory to locate company's vision. Source: Author.

time has been re-introduced into the analysis after it has been expelled from the two-dimensional economics [16] and from linear management [13].

Complexity Theory ${ }^{15}$ (Figure 5) is a broader concept than Chaos Theory.

The above four theories have been united by Cowan G A (1920-2012) in 1942 [17]. Cowan was also the driving force, together with Murray Gell-Mann (1929-), behind the foundation of $\mathrm{SFI}^{16}$. Important is in 1970, where Conway (1937-) [18] invented the "game of life"-An automaton ${ }^{17}$.

\section{Part II: A Brief History of Chaos Theory (1889-)}

Chaos theory [17] begun in 1889 emerging from the attempted solution of the problem of the "three bodies", or in other words, of the stability of Solar system. The French mathematician Poincare A (1854-1912) worked-out a partial solution, when he first glanced at the exceptional complexity involved (=chaos) (known as the "homoclinic tangle", meaning a tangle having same bend) [16].

People's attitude, however, was against the above endeavor: people avoided all along complexity, and preferred simple structures, which reduced complex things to simple ones (=reductionism). Beauty surely can be found in simplicity. This does not mean that complex systems do not exist, or are inferior in beauty [1]. Managing firms and industries, as well economies are considered as equivalent to managing complex nonlinear systems (CNS)! The concept of the attractor was not unknown in the past, but it was known as the ellipticorbit (trajectory) of a planet, where disturbances are kept within specific limits. This concept passed as ${ }^{15}$ Complexity science covers: cognitive science, ecology, evolution, game theory, linguistics, social science (economics), computer science, genetics, immunology, laser, history, management, medicine, finance and philosophy as well others [11], p. 16.

${ }^{16}$ Universe is complex, because is integrated, too rich and varied to be understood using linear ways, except for parts of it, and the rest by principles and patterns with no detail (a modified definition from Santa Fe Group (in 1996)).

${ }^{17}$ A computer program invented in the mid-1950s by von Neumann J to study self-replication. 


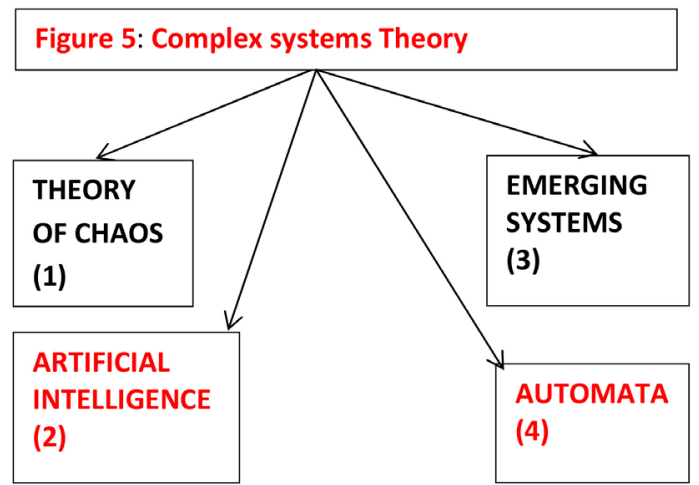

Figure 5. Complex systems theory. Source: Author.

a metaphor to humans and thus we have "management by attractors" and not by hierarchy!

Chaos is clearly shown in mathematics: e.g. in the simple logistic (difference) equation of the second order. $\mathrm{z}=\lambda \mathrm{z}(1-\mathrm{z})\{1\}$ by giving, in a computer, various values $(0-4)$ to the (unique) parameter $\lambda$ (e.g. $\lambda=0.8,1.5,3$ and 3.55) and $z=$ 0.5. This equation neither departs, nor approaches one single value, but most important is that, at some point, becomes chaotic!

On the other hand, Randomness, which is the antipode of Chaos, has no structure. Important is that many physical dynamic systems (PDS) behave chaotically. Thus a whole theory emerged i.e. Complexity Theory to study how stable structures emerge.

The main point of Chaos Theory is that certain physical systems (PS) have the same characteristics of social systems (SS), with similar mathematical behavior, like the complex adaptive systems (CAS). These are subsets of nonlinear $d y$ namic systems ${ }^{18}(N D S)$. Important is that these systems have negative or positive feedback; the second term is by now used in nonlinear Management. The characteristics of these systems are: self-similarity ${ }^{19}$, complexity, emerging ability and a self-organizing behavior [19]. Worth noting is also that the DNA structure, invented in 1953, fits to the analysis of Von Neumann ${ }^{20} \mathrm{~J}$ (1903-1957) of the mathematical properties of the self-replicating systems.

\section{The Four Universal Classes}

In 1984, Wolfram S (1959-) remarked that the automata have intense similarities with the ND. He classed them in four universal classes: I, II, III and IV (Figure 6). Worth noting is that class IV comes before class III, as argued by Langton C (1949-), meaning that chaos comes after complexity! This is important for management, as companies have a strategy to get out of chaos if they are in and not to get into it if they are not in.

${ }^{18}$ Such systems are: the human immune, embryo's growth, financial markets, and political parties. Also, climates, cities, firms, markets, governments, industries, traffic flows, internet, cyberspace and others.

${ }^{19}$ A simple example: a branch is self-similar to its tree.

${ }^{20}$ The game of life is a cellular automaton, i.e. a computer program studying self-replication having life's features. 


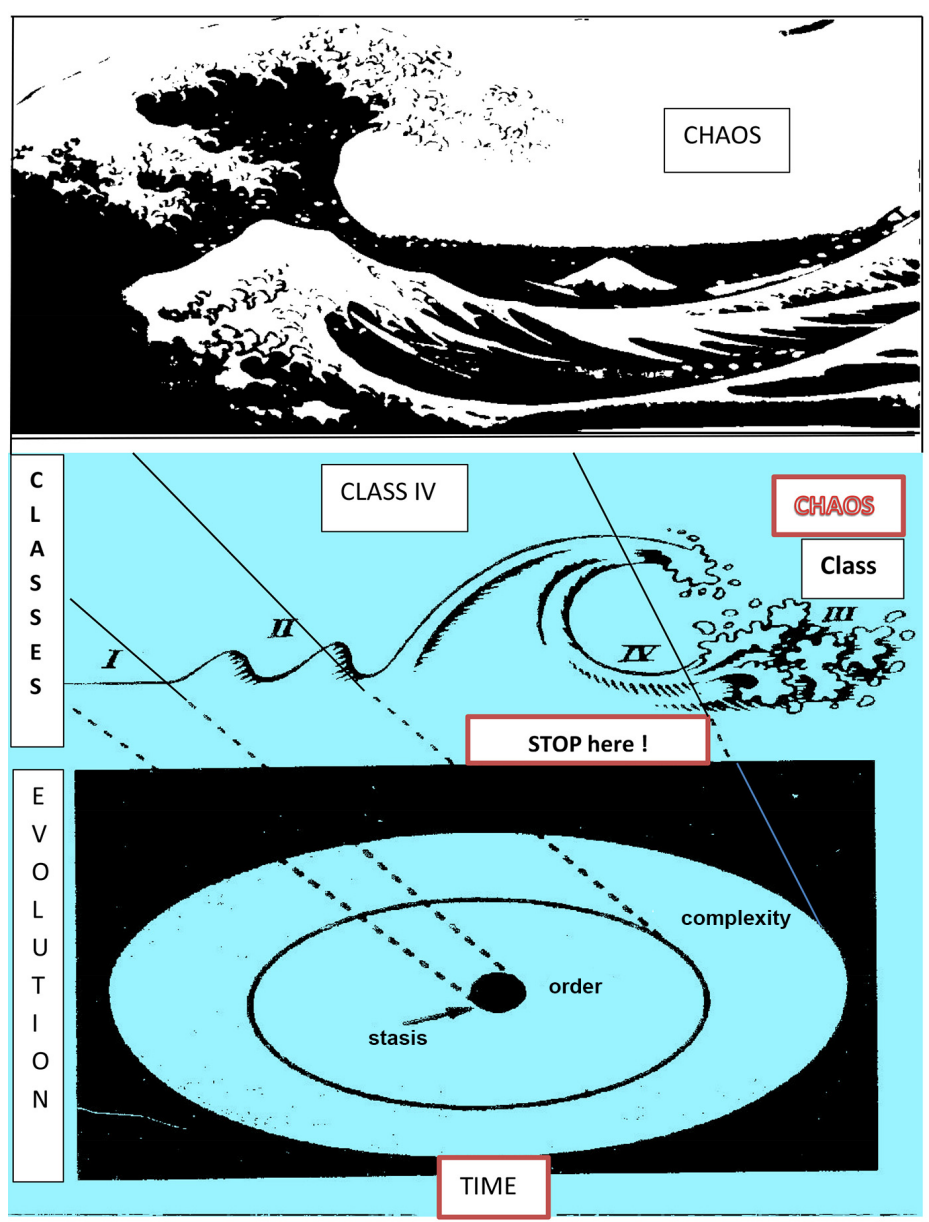

Figure 6. The four universal classes in nonlinear dynamics. Source: Author; modified from Battram [11], p. 141, and Stopford [21].

As shown, class I (=stasis) and class II (=order) offer static solutions, after a small number of (life) cycles; Class I ends at one steady and fixed structure, while class II ends at a stable periodic structure. Given that the world of businesses is dynamic, then these classes and especially I, must be considered as transitory. In Class III we encounter chaos, without a visible structure (a metaphor = the dangerous area in surfing is chaotic)!

The game of life is played in Class IV, as well in other systems of emerging order and for innovation. Their companies must try to be and stay. Chaos Theory thus provides managers a business strategy: get one's company across classes I and II in their early stages and then companies must try to be and stay in class IV. IBM e.g. was in class II in 1980s and Microsoft was also in class II in end-1970s (Figure 7).

As shown, Microsoft, over six years in 1970s, performed a sustained rise in both assets and profits; also, company showed a stability; company's trajectories progressively advanced into Q1 [5] indicating a balanced course between assets and profits. It is, however, recommended that company pursued the blue trajectory where profits rise faster than assets. 


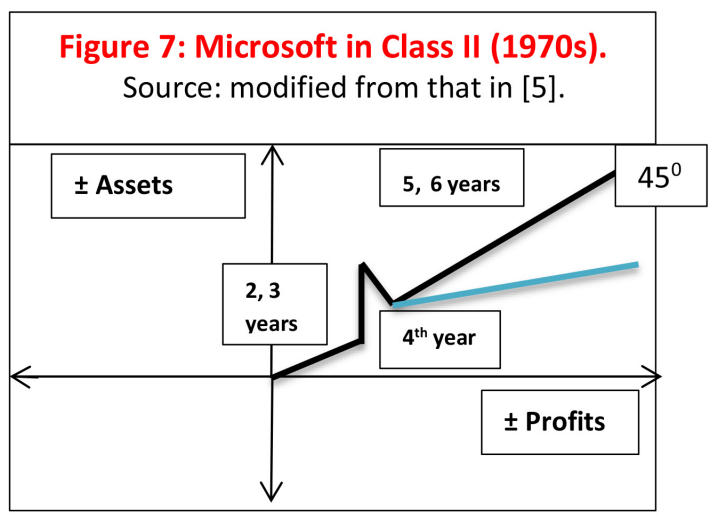

Years 2 and 3 show a proportional greater increase in profits than in assets. Years 5 and 6 show constant rises ( $45^{\circ}$ degrees) in both. This means a balanced increase in both assets and profits. indicates Class IV. This last course is better than the black one at $45^{\circ}$.

Figure 7. Microsoft in Class II (1970s). Source: modified from that in [5].

\section{Part III: Important Linear Management Concepts}

We cannot say that humans discovered management for the first time in 1911. Management is an everyday science practiced all along with mankind's history, even with no theory, by necessity and common sense. It is the science of action, than inaction. In many occasions, men had to: hire staff, to organize, to direct and to span management (Moses in Bible applied delegation on suggestion from his father in law; Pyramids; Chinese Great Wall; Acropolis (Athens)), by instinct using their brain.

Only Noah, the first global shipbuilder, and ship owner of passengers, and livestock in bulk, commanded by God, was the one to need help for ark's plans. Robbins and Coulter [20] distinguished management approaches in five, which due to overlapping we reduced them to three: 1) the early: from 3000 B.C. to 1776, including a behavioral one from 1700 to 1950;2) the classical: from 1911 to 1947 , including a quantitative one: from 1940 to 1950 (or 1960?) and contemporary: from 1960 till this day. In this last during, we have to include the Digital Management, which appeared in 1980s and followed the electronics and information technology in mid-1970s. This will occupy us in another paper.

\subsection{The Main Theories Created by Management, 1911-1991}

The official birth of Management science occurred in 1911 (Figure 8).

As shown, the evolution of management, from 1911 to 1991 (80 years), built on nine major theories, one in almost every 10 years. 1) Taylor F. W. in USA (1911) was the first to write a book on management, who called it "scientific ${ }^{21}$ " being also an industrial manager. This influenced also Japan.

2) Worth noting is that the issues concerning human resources emerged as early as in 1927, mainly in USA, due to the fact that the prevalent opinion was that humans had better to perform as machines. This is the age of mechanization and the aftermath of the $1^{\text {st }}$ Industrial Revolution ${ }^{22}$.

${ }^{21} \mathrm{He}$ implicitly characterized previous attempts as non-scientific.

${ }^{22}$ The $1^{\text {st }}$ Ind. Revolution was based on water and steam to mechanize production before 1889 . 


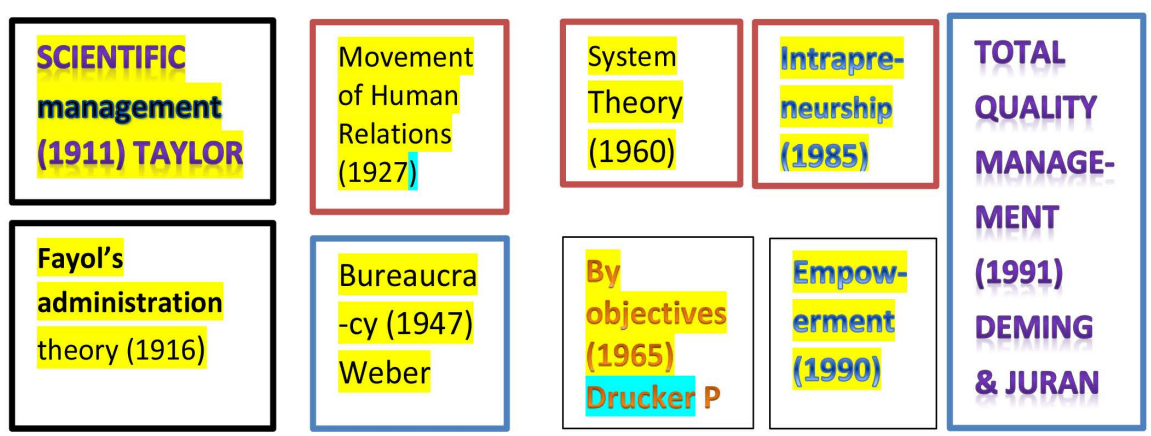

Figure 8. The traditional evolution of Management Science, 1911-1991. Source: Inspired by table 7.1 in Priesmeyer (1992) [5] (p. 154) and Robbins and Coulter (2018) [20], p. 74.

3) Europe created its management theory with a 5-yearly delay, vis-à-vis USA,by providing a management book in 1916, by another industrial manager, Mr. Fayol H from France. Fayol was the one to influence European management and the Greek public sector as well.

4) Weber M (1947) wrote his book based on an organization cast in many offices (bureaus), and controls ${ }^{23}$, influenced by his German character and his sociological studies. Bureaucracy is thus defined as the form of organization characterized by the (celebrated) division of labor, a clearly defined hierarchy, detailed rules and regulations, and impersonal relationships.

The above three books dominated the first 50 years or so of management, we believe. The structure of a vessel is not far away from the above model of Weber.

The main difficulty for Management, at least for the first 50 years or so, is that most papers works had to be carried out from people managing companies, i.e. from inside.

5) Important, however, was the system (1960) or systems theory (1960-1980) arguing, among other things, that companies are interactive sub-systems and more important is that they interface with their externa $P^{4}$ environment.

Given also that a large company has power and money, and perhaps it can influence current governments ${ }^{25}$, society created additional demands and expectations on it (=social responsibility). This is a business' intention, beyond its legal and economic obligations, to do the right things and act in ways that are good for society. Companies are expected today to be allies with both their staff and its

${ }^{23}$ One office in lower level is controlled by the next higher office, and so on, till a matter passes all offices, and finally reaches top-management, where decision is taken. This is surely a suitable structure to manage Armies and very large companies. This is, however, a paradigm of bureaucracy (dominance of offices), where control is more effective. Shipping companies are flirting with this structure.

${ }^{24}$ Companies before 1960 based their success on its technical perfection, ignoring the existence of customers! The external environment, however, was that which created at times protestors, civil rights demands and reactions on international events (like the Vietnam War). More recently external environment has created a massive immigration, a re-appearing terrorism that approaches even companies' staff, piracy and a religious-based violence. Today competition and climatic change are also the major players in external environment.

${ }^{25}$ (Greek) Shipowners are not aggressive with all types of governments, but more cordially are with the right wing ones. They prefer the Laissez-Faire external environment. 
local community.

6) Another idea came from the fact that entrepreneurship was a sought-after property in general to create ${ }^{26}$ new business units; so management demanded employees to become small entrepreneurs within their companies (1985)! The trend clearly was towards valuing-up employees' role in companies, as a reaction to the past mal-treatment of labor by capital (UK Marx; 1818-1883). This boosted also the idea that education has to continue and after graduation, conceiving a company as a living person (-ality ${ }^{27}$ ) consisting by a set of human personalities. As argued by Socrates (469-399 B.C.): "As I get older, I always learn lessons".

7) Labor's upgrading produced also empowerment claims (1990), followed by total quality management (1991). Another reason was that "one single bird (= the manager) cannot bring a Spring" (profits), as argued by a popular Greek saying; so managers need upper (divisional; departmental) and middle managers (operators in shipping; Captains; chief Engineers) to carry-out company's operations. Business became teamwork. Today there are firms managed by distance at a minimum interference from management. Management acts as a consultant.

8) Total quality management was also an effort to increase the responsibility of all employees towards a fuller satisfaction of the customer-the key-figure in businesses. Satisfaction to customer comes from everyon $\mathrm{e}^{28}$ and everything in a company, not just from the quality of its products or services.

Our experience from a long departmental managership is that top-management and employees must improve their financial status in proportion to their contribution to company's profits. This, as we showed, puts a greater pressure on the staff holding company's shares.

So the profile of management, as presented above, is that new ideas come and go, and few stay, but all proclaim to be a panacea when they first emerge; a set of shooting stars! Examples: "management by objectives"29; "total quality management"30; "total safety management" ${ }^{26}$ Managers manage companies which have been created by entrepreneurs...

${ }^{27}$ Companies thus, by this metaphor, are considered as living organisms having brain, capital (human), memory, ideology (culture), experience, knowledge, etc. and they need a further learning and continuous education. A company is superior to another to the extent that all above properties are superiorly embodied in company's staff and crew. Shipping companies help their staff in matters of health, in economic difficulties (loans) and after marine accidents (crew's deaths).

${ }^{28}$ Even from the girl in companies' switch board.

${ }^{29}$ This is the process of setting mutually agreed-upon goals and using them to evaluate employee performance. Priesmeyer [5] argued that MbO worked (p. 154).

${ }^{30} \mathrm{TQM}=\mathrm{A}$ philosophy of management that is driven by the continuous improvement and responsiveness to customer's/charterer's needs and expectations.

${ }^{31}$ TSM replaces TQM in cases where safety is more important and prior than quality, e.g. in case the cargo is lost, quality is gone! In transport, the delivery of the same quantity and condition of cargo loaded is more important than the total time of transport, considered this last as a quality element!

${ }^{32}$ This is a performance measurement tool that looks at more than just the financial perspective of the company. Management after some time quite rightly demanded to measure results. 
management" 33 and "contingency approach"

\subsection{Management's Inheritance}

Scientists from different sciences influence one another. Management has a tradition of borrowing ideas from sciences (Physics, Mathematics, Sociology, Economics, Psychology etc.) in its search for the latest solution [11].

At the beginning of this century, the theories of Darwin ${ }^{35}$ (1809-1882), Freud ${ }^{36}$ (1856-1939), Einstein ${ }^{37}$ (1879-1955), and Schrodinger ${ }^{38}$ (1887-1953), whether right or not, demolished the foundations of the 300-year dominance of the Newtonian (1642-1727) logic [11].

But before the "un-nailing" of Newtonian ideas, rooted in management, the three main principles, on which early management was based, till this day, are: 1) reductionism, which we mentioned, (i.e. make a complex world simpler), 2) determinism (forecasting is quite feasible, as argued by Descartes ${ }^{39} \mathrm{R}$ (1596-1650) and 3) equilibrium is attainable (a desirable state, but deceptive, borrowed from Physics by economics for the latter to become an exact science!) [16].

Managers admired machines, as mentioned, which were newly introduced into the production in new factories, for their obvious merits: accuracy, speed, punctuality, obedience, no counter-argumentation. Machines, however, required control. Managers, following Fayol mainly, saw that what they needed to do is to treat humans as machines-a metaphor $\left(\operatorname{Morgan}^{40},[6]\right)$.

This further meant that management should be embedded in plans, i.e. planning, budgeting and "management by objectives". Machines established a centralized, bureaucratic structure, which could achieve a state where command and control is applicable.

\footnotetext{
${ }^{33}$ Known as benchmarking, i.e. the search for the best practices mainly among competitors (but also among non-competitors) that led to their superior performance. In other words: "you have to do also what others do better"!

${ }^{34}$ This recognizes that companies are different, facing different situations, and thus requiring different ways of management. True that each personality is different and thus needs differential treatment. Managers prefer across the board policies which are easier and impartial (e.g. wage rises). This introduced pluralism in management meaning that there are no simplistic or universal rules for managers to follow.

${ }^{35}$ In 1859 he argued that the process of natural selection tends to favor the survival of those best adapted to their environment. While this is also true for companies according to System Theory, the conclusion that new species may arise widely different from each other and from their parents can not be supported. If we believe in Bible, today's population comes from only 3 - 4 couples who disembarked from Ark, including Noah and his wife. Moreover, the DNA Theory does not prove Darwin's theory as the basic characteristics (and even illnesses) that pass from parents to children pass also from generation to generation. Darwin committed the mistake to identify humans as another perfected kind of animal. Humans possess soul and brain. Apes so far did not make any invention at all to convince as our predecessors.

${ }^{36}$ Neurologist and psycho-analyst focused mainly on human sexual attitudes.

${ }^{37} \mathrm{He}$ was the founder of relativity theory and randomness.

${ }^{38} \mathrm{He}$ was known for his quantum theory and his wave function. He also inspired the search for DNA (1953).

${ }^{39}$ The universe can be reduced to three: space, matter and motion (1637), operating under mathematical laws.

${ }^{40}$ Morgan analyzed a series of metaphors used to describe companies, pointing-out that metaphors can be very restrictive. A "cost center" is a metaphor meaning that cost is a bad thing. Cost has surely two sides-bad and good.
} 
Table 1 shows the basic tools of linear management.

\section{Part IV: The Two Basic Terms in Management}

\subsection{Mission}

The mission indicates: 1) the industry, in which company will be; 2) the market, which company will serve; 3 ) the technology, which company will use ${ }^{41}$. Linear management argues that mission must be defined after a company examined its external and internal environment. Some believe that mission should not be frequently changed.

A good question is: are all missions attainable? This cannot be always true, unless mission is vaguely defined, like e.g. a firm, which stated that its mission is to "become dominant supplier of consumer products for so and so". This mission statement cannot be understood till company specifies what the word dominant means.

Vagueness we encountered also in the mission statement of EL shipping company (in the case study), saying that the company will "become leader and world's largest owner" (Table 2). This mission statement, though very ambitious, can be achieved in theory, because it does not specify: time, number of ships or their dwt, technology to be used, market and industry. So, whatever result comes out, company can say afterwards that it has accomplished its mission!

Table 2 summarizes companies' mission.

Companies like to add, to their mission, philosophical/psychological elements. E.g. a shipping company may state: our mission is: "to transport 365 days in a year with no marine accident". The mission directs a company in general terms. So, a corporate mission statement should define what a company is trying to do, and how it intends to do it. Mission is born out of an initial idea of company's founder, we believe, to meet a forthcoming need, which he alone saw. If mission is successful means that founder's foresight was correct.

However societal needs change. Our opinion is that a mission has to be adaptive over changing circumstances till mission disappears! Technology also changes. Greek Heraclitus (c. 513 B.C.) quoted to have said that one cannot step into the same river twice, meaning: a river's waters, due to their continuous flow, are not the same over time, so one cannot step in a river for a second time and expect to meet the waters he/she met previously! Everything is flowing. This indicates the dynamics of Nature and Life.

\subsection{Vision}

The Vision of a company is many times more important (Table 3) than mission.

As shown, managers should have a vision. If a shipping top-manager says that "by 2022 the company will own another 5 newly-built Eco-tanker ships of Panamax size with double-hull", this is a vision. Vision is a claim against the

${ }^{41}$ One must be careful about this for many mistakes occur. 
Table 1. Control mechanisms making employees to work as machines.

\begin{tabular}{cccc}
\hline Monetary rewards & Punishments & $\begin{array}{c}\text { Division of labor } \\
\text { (Adam Smith) }\end{array}$ & Setting tasks \\
\hline $\begin{array}{c}\text { Interchangeability } \\
\text { of parts }\end{array}$ & Standardized procedures & Quality control (TQM) & Cost accounting \\
$\begin{array}{c}\text { Time and motion } \\
\text { studies in post- } \\
\text { Taylorism epoch }\end{array}$ & Organizational charts & Budget & Review performance \\
Audits & Standards & Negative feedback & Hierarchy $\left(^{*}\right)$
\end{tabular}

Source: Battram, (1998), [11], pp. 9, 20-21, 39. $\left(^{*}\right)$ Management by Chaos is not based on hierarchy, but on person (-ified) attractor(s)! The "person-attractor" is the one in companies who has all the solutions, no matter his/her position! Management has to work with attractors, not with those in hierarchy...if not attractors!

Table 2. The mission of a (shipping) company.

\begin{tabular}{llll}
\hline $\begin{array}{l}\text { Mission designates the } \\
\text { (broadly termed) purpose }\end{array}$ & $\begin{array}{l}\text { Defines firm's } \\
\text { or reason or a (shipping) } \\
\text { firm to be in the market }\end{array}$ & $\begin{array}{l}\text { Identifies the type of } \\
\text { technology to be used }\end{array}$ & $\begin{array}{l}\text { Focus attention on } \\
\text { the company }\end{array}$ \\
$\begin{array}{l}\text { Serves as a guiding } \\
\text { principle for } \\
\text { decision-making }\end{array}$ & $\begin{array}{l}\text { Ensures not to take } \\
\text { conflicting initiatives philosophical or ethical } \\
\text { (by the company) }\end{array}$ & $\begin{array}{l}\text { Broadly stated describes } \\
\text { thentions specific }\end{array}$ & $\begin{array}{l}\text { Narkets, tactics } \\
\text { and/or technologies }\end{array}$
\end{tabular}

Source: Inspired from Priesmeyer [5].

Table 3. The 12 roles of vision of a (shipping) company.

\begin{tabular}{llll}
$\begin{array}{l}\text { Identifies the } \\
\begin{array}{l}\text { (specific) future state } \\
\text { of the company }\end{array}\end{array}$ & $\begin{array}{l}\text { Quantifies a } \\
\text { (broad) mission } \\
\text { statement }\end{array}$ & Has many dimensions & $\begin{array}{l}\text { Helps managers to define } \\
\text { the future they want }\end{array}$ \\
\hline $\begin{array}{l}\text { Means discernment, } \\
\text { foresight, insight, } \\
\text { imagination } \\
\text { dreaming }\end{array}$ & $\begin{array}{l}\text { Provides ways to } \\
\text { relate short term \& } \\
\text { long term decisions }\end{array}$ & $\begin{array}{l}\text { Is the process of choosing } \\
\text { and creating company's } \\
\text { future }\end{array}$ \\
$\begin{array}{l}\text { A technique of } \\
\text { planning-based on the } \\
\begin{array}{l}\text { current state of the firm } \\
\text { and on its way evolving } \\
\text { incrementally }\end{array}\end{array}$ & $\begin{array}{l}\text { Controls the } \\
\text { current state }\end{array}$ & $\begin{array}{l}\text { Controls system's } \\
\text { evolution }\end{array}$ & $\begin{array}{l}\text { Allows taking firm } \\
\text { anywhere }\end{array}$
\end{tabular}

Source: Inspired from Priesmeyer [5].

future. Vision takes the mission and translates it into quantities and places it in future time. Vision is defined after company has designed the future it wants. Vision has nothing to do with projecting or estimating. Vision is choosing and creating company's future.

To be clear we use an example (Table 4).

\subsection{The Mission of a Shipping Company}

Table 5 presents the mission of Greek shipping company (the Eletson Corporation-EL (1966)), transporting oil products (Appendix 2). Despite company's 
Table 4. The four concepts re-stated using as an example a hospital.

\begin{tabular}{|c|c|c|}
\hline Area & Statement & Remarks \\
\hline Mission & $\begin{array}{l}\text { To provide quality medical care to the } \\
\text { population of North Athens }\end{array}$ & $\begin{array}{l}\text { This is to provide an overall guide to what } \\
\text { hospital's members think important }\end{array}$ \\
\hline Vision & $\begin{array}{l}\text { To attain a bed capacity of } 300 \text { beds, } \\
\text { and a budget surplus of } \$ 100,000 \text { by } \\
\text { June } 30^{\text {th }}, 2020\end{array}$ & Two quantitative elements and time! \\
\hline Goals & $\begin{array}{l}\text { To re-model Hospital's East Wing } \\
\text { within next } 6 \text { months, and reduce } \\
\text { utility costs by } 15 \% \text { in } 12 \text { months }\end{array}$ & $\begin{array}{l}\text { Short-term concept; subject to company's } \\
\text { mission and subordinate to it; it is purposed } \\
\text { to challenge or motivate personnel in } \\
\text { operations, or facilitate an efficient budget }\end{array}$ \\
\hline Objectives & $\begin{array}{l}\text { To re-model Hospital's East Wing } \\
\text { within next } 6 \text { months, and reduce } \\
\text { utility costs by } 15 \% \text { in } 12 \text { months }\end{array}$ & $\begin{array}{l}\text { Short-term concept; it is purposed to } \\
\text { challenge personnel in operations; threshold } \\
\text { performance level stated for the purpose of } \\
\text { motivating personnel, or crew, or facilitate } \\
\text { an efficient budget }\end{array}$ \\
\hline
\end{tabular}

Source: inspired from [5].

Table 5. EL's mission.

\begin{tabular}{|c|c|c|c|}
\hline Mission & Vision & Goals & Objectives \\
\hline $\begin{array}{l}\text { To transport oil products; to be leader; to } \\
\text { gain the respect of international market; } \\
\text { to own world's largest fleet of medium } \\
\text { and long range product tankers; to meet, } \\
\text { professionally, clients' needs; to be } \\
\text { recognized as the best, in class, among oil } \\
\text { products marine transportation shipping } \\
\text { companies worldwide }\end{array}$ & $?$ & $\begin{array}{l}\text { To be sensitive to sea } \\
\text { environment; to be } \\
\text { committed to quality }\end{array}$ & $\begin{array}{l}\text { To complete } \\
\text { voyages on time, } \\
\text { injury-free, and } \\
\text { without a drop of oil } \\
\text { spilled; to attend } \\
\text { safety; to own a } \\
\text { young fleet; }\end{array}$ \\
\hline
\end{tabular}

Source: Compiled from company's booklet (2001).

size of almost $2 \mathrm{~m}$ dwt of 29 ships and 15 LPG/NH3/LEG of 305,940 cbm (2015), company's booklet provided no vision; the vision, which is stated by the company as such, is really a mission; it lacks elements of time and of specific quantities to be achieved.

As shown, company describes its mission, stating the market and the industry it serves (oil products); the technology it uses (medium and long range tankers). The young fleet mentioned is not a mission, but an objective for owners, and it could be better stated as e.g.: "company intends to own tonnage of an average age below 5 years of age through new buildings".

Then it puts all its emphasis on one single issue, i.e. safety, which is stated in 5 different statements. 1) to gain the respect of the international market; 2) to be commited to quality; 3) to be sensitive to sea environment; 4) to complete a voyage injury-free, without a drop of oil spilled; and 5) to attend safety. All above 5 statements are equivalent, some are for crew and EL's personnel, meaning indirectly that the company will comply with ISM Code ${ }^{42}$, which, was com${ }^{42}$ International code for the safe management of ships, due to IMO, drafted etc. as a result of the marine accident in 1987 of the passenger vessel "Spirit of Free Enterprise", off a Belgian port. 
pulsory (since 01/07/1998) for all shiponwers (revised in 2002).

Worth noting is that quality is a misleading term for shipping (service) companies, borrowed from products. There is not so much quality in sea transport ${ }^{43}$ as much as safety. Perhaps it would suffice for the company to state, as its mission, that "company's management pays all efforts not to allow any marine accident to occur by company's ships".

Moreover, there are statements in company's mission of a phychological or philosophical kind: for "the company to be leader"; "to own world's largest fleet"; "to be recognized as the best shipping company worldwide". Next, there are more statements that concern company's customers/charterers: "voyages will be completed on time"; "company meets professionally clients' needs". Strangely there is no reference to the particular technology to be used like that of double-hull for which EL was proud, as it adopted it three years in advance of the appearance of law!

\section{Part V: EL Shipping Company: A Case-Study}

\subsection{Company's Revenue Performance}

The revenue performance of EL, taking only changes from 1988 to 2000 (where data is available), indicates a cyclical and rising pattern, starting from $\$ 57 \mathrm{~m}$ in 1988 to $\$ 203 \mathrm{~m}$ in 2000 (yearly positive changes) (Figure 9). This pattern reminds us of Onassis's strategy, who he too bet on the right horses, i.e. newly-built large crude oil tankers, till energy crisss emerged but after his death. These owners assume that in the long-run demand ${ }^{44}$ will surpass supply despite any yearly fluctuations. They proved to be right! This policy gave to EL revenue of $\$ 1.472 \mathrm{~m}$ in 12 years. Company accepted its future exactly as defined by the market.

Figure 9 is a Q1-quadrant diagram, meaning that variables are presented only inabsolutes positive values. We sliced EL's performance (production) in three four-yearly periods (shown byarrows). EL's revenue eventually doubled in the first period (1988-1992); trebled during next period (1992+ to 1997+) (best period) and finally rose 4 times since 1988 (1997+ to 2000) with a deep and continuous fall in between.

In terms of changes, EL increased its production substantially in 1990-1991 by $1.24 \mathrm{~m}$ metric tons transported; in $1991-1992$ by $3.01 \mathrm{~m}$; in $1994-1995$ by $1.96 \mathrm{~m}$ and in 1999-2000 by $3.20 \mathrm{~m}$, mainly through new buildings. Market compensated company open-handed only in 2000 with additional revenue of $\$ 82 \mathrm{~m}$; much less in 1994-1995 by $\$ 31.5 \mathrm{~m}$; less in 1990-1991 by $\sim 15 \mathrm{~m}$ and less in 1991-1992 by $\$ 9.5 \mathrm{~m}$. Market works on supply and demand and not on quality.

Astonishing is the fact that shipping companies decide, especially those with

${ }^{43}$ Quality in shipping is to deliver cargo safely to the appropriate recipient, as agreed in the charter party, in the same condition and quantity loaded. This means safety.

${ }^{44}$ In shipping demand is a derived demand. The transport of oil products is based on people's standard of living, like car ownership, air transport (jet fuel); transport in general (fuel and diesel), wars, chemicals, paints etc. Imagine Chinese people and that of India ( $2+\mathrm{b}$ people) to obtain 3 cars each as in USA and Europe and their need for gasoline. One must care about climatic change and if gas will replace oil. 


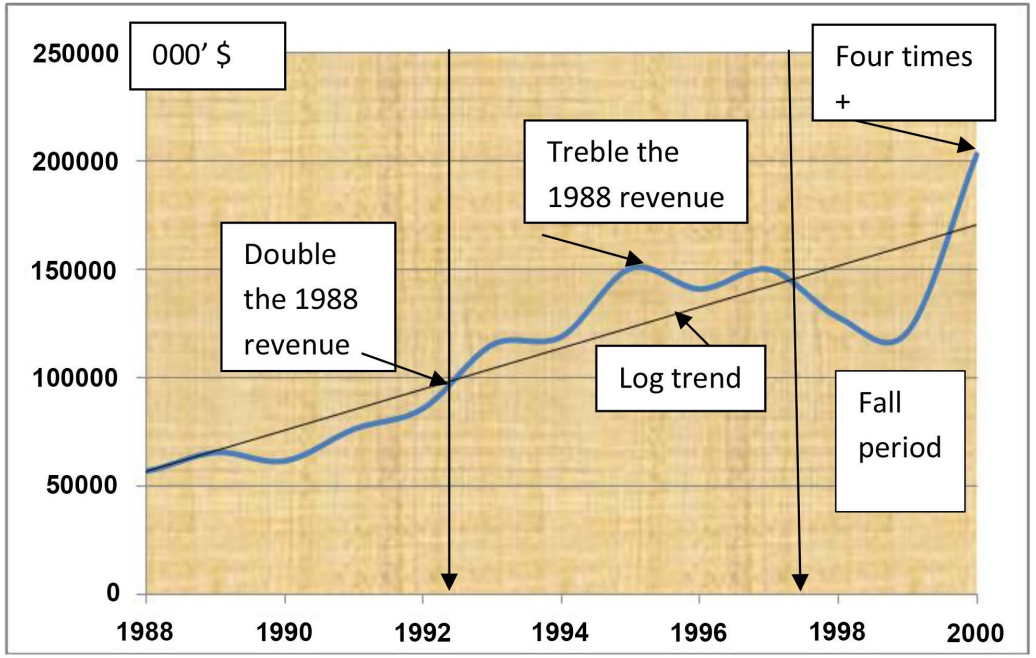

Figure 9. EL's revenue (000's US\$), 1988-2000. Source: data from company's booklet, Sept. 2001.

serious ship building programs, without any reference (or forecasting) to the condition of the market these ships will encounter upon delivery! Though newly-built ships may force old ships to lay-up, given demand, this new tonnage will lower the freight rates for all ships, new and second hand due to an increased supply. EL argued that it performed better than the others and despite that others have time-chartered ships.

\subsection{The Condition of Demand of Oil Products, 1988-2000 (Imports)}

Let us see the condition of the market closer (i.e. the trade of oil products-imports) (Figure 10) before we proceed.

As shown, the trade of oil products (imports) ${ }^{45}$ fluctuated violently down by $\sim 100 \mathrm{mt}$ from 1992 to 1993, though rising in the long run. Imports are equal to exports. This figure must be considered as an approximate representation of reality, as it was read from a diagram [21].

In 1989-1990, trade was stagnant, rising in 1991 by $9 \%$. A great leap forward took place in 1992-1993, then a set back in 1994 to 1991 level, and this continued in 1995-200 with small rises to $443 \mathrm{~m} \mathrm{mt}$ in 2000 from $374 \mathrm{~m} \mathrm{mt}$ in 1995 (+10\%). Comparing Figure 10 with 9, EL's revenue, followed trade. Trade from $\sim 130 \mathrm{~m}$ in 1963 rose to $\sim 653 \mathrm{~m}$ in 2007 ( 5 times up) despite severe fluctuations at times (1995-2000).

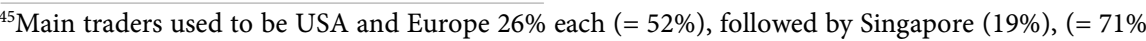
total out of $658 \mathrm{~m}$ tons in 2006). USA (except in 1971-1975 of $150 \mathrm{~m}$ ) and Europe (except $100 \mathrm{~m}$ in 1991) showed a rather modest rise from 1963 to 2007. "Other countries" had a leap forward from 1988 to 2007 from $77 \mathrm{~m}$ to $320 \mathrm{~m}$ ! Other countries were: China 11\%, Africa $11 \%$, L America $11 \%$ and other Asia $41 \%$. It matters from where oil products go to USA (i.e. from Caribbean); M East raised its refinery capacity in 1980s. In 2007 "others" had 47\%; USA 25\%; Europe 20\% and Japan $8 \%$. It matters where refineries are and the distances involved. Refineries after oil crises moved away from places they were and from war areas in M. East (1974-1979). Important oil products related to civilization are: gasoline (38\%); fuel oil $37 \%$ as well others.
} 


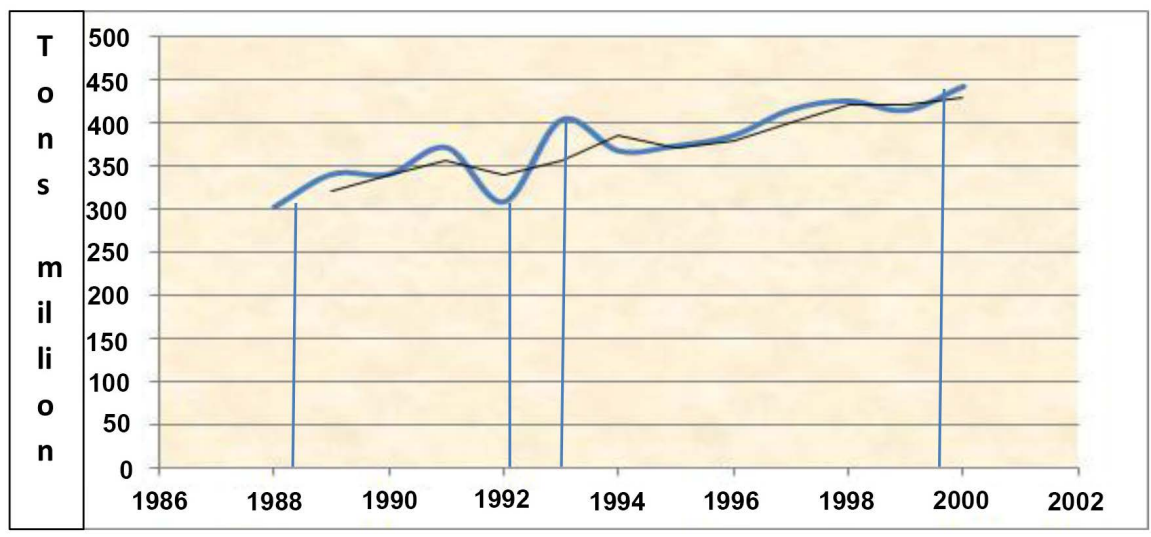

Figure 10. Oil products trade (world imports) 1988-2000 in m. tons. Source: Read from Stopford (2009), [21], p. 444.

One reason for EL's fluctuating revenue is that company preferred the spot market, instead of time-charter, given that spot freight rate's fluctuations are more violent. During 1991-2001, only 10\% of company's tonnage was in time charters. EL explained this by arguing [22]; Lloyd's Shipping Economist monthly journal (out of circulation) [23] that the company had a policy to be in the spot market. A question remains: why to stay in a bad spot market, probably gaining more than the other owners, but getting at least $\$ 42 \mathrm{~m}$ less?

\subsection{EL's Production Performance}

The production performance of EL (Figure 11) is next shown. Figure 11 is also a Q1-quadrant diagram.

As shown, the pattern of production (=sales) is similar to that of revenue. This implies that as EL's fleet increased ${ }^{46}$, revenue increased. But has revenue increased proportionally or faster? We will find this by using changes invariables, or a 4-quadrant Cartesian diagram.

\subsection{Chaos in EL's Performance}

We take into account changes ${ }^{47}$ in variables, as we did in Figure 1. On vertical axis we mark changes in company's yearly earnings (=revenue) and on the horizontal axis we mark changes in yearly sales (=cargo transported). Then, EL's limit cycle is shown (Figure 12) for the first period (1988-1992).

EL's sales rose by $1.08 \mathrm{~m}$ tons (1988-1989), bringing-in an additional revenue of $\$ 8.6 \mathrm{~m}$. Next year (1989-1990) figures were negative: company's sales (cargo transported) fell by $1.16 \mathrm{~m}$ metric tons and sales fell by $\$ 3.96 \mathrm{~m}$. In 1990-1991 figures were positive: sales rose by $1.24 \mathrm{~m}$ bringing-in additional revenue of $\$ 14.8 \mathrm{~m}$. Sales continued in a more modest manner innext year (1991-1992): sales rose by $3 \mathrm{~m}$ bringing in $\$ 9.54 \mathrm{~m}$ (at a low freight market). Company's trajectories visited 1, 3, 1, and 1: a 2-period (low) order of chaos.

${ }^{46}$ Fleet/production fell in 1989-1990 and in 1995-1997.

${ }^{47}$ This has a price: we lose the first observation. 


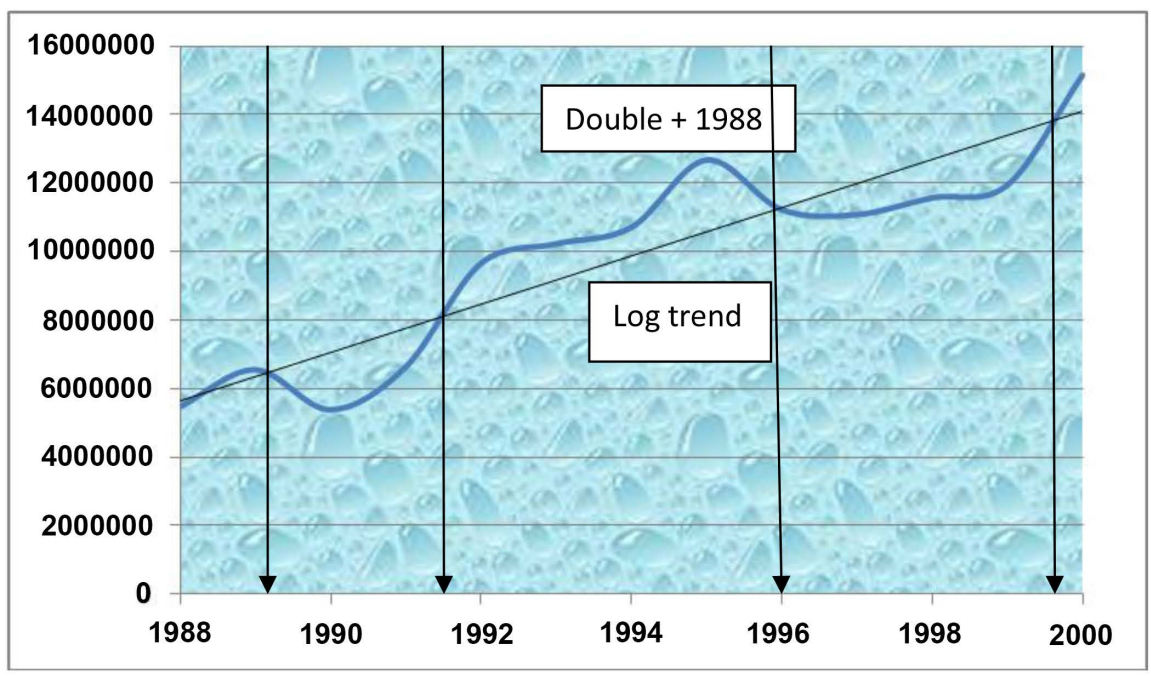

Figure 11. Cargo carried by Eletson, in metric tons, 1988-2000. Source: data from company's booklet, Sept. 2001.

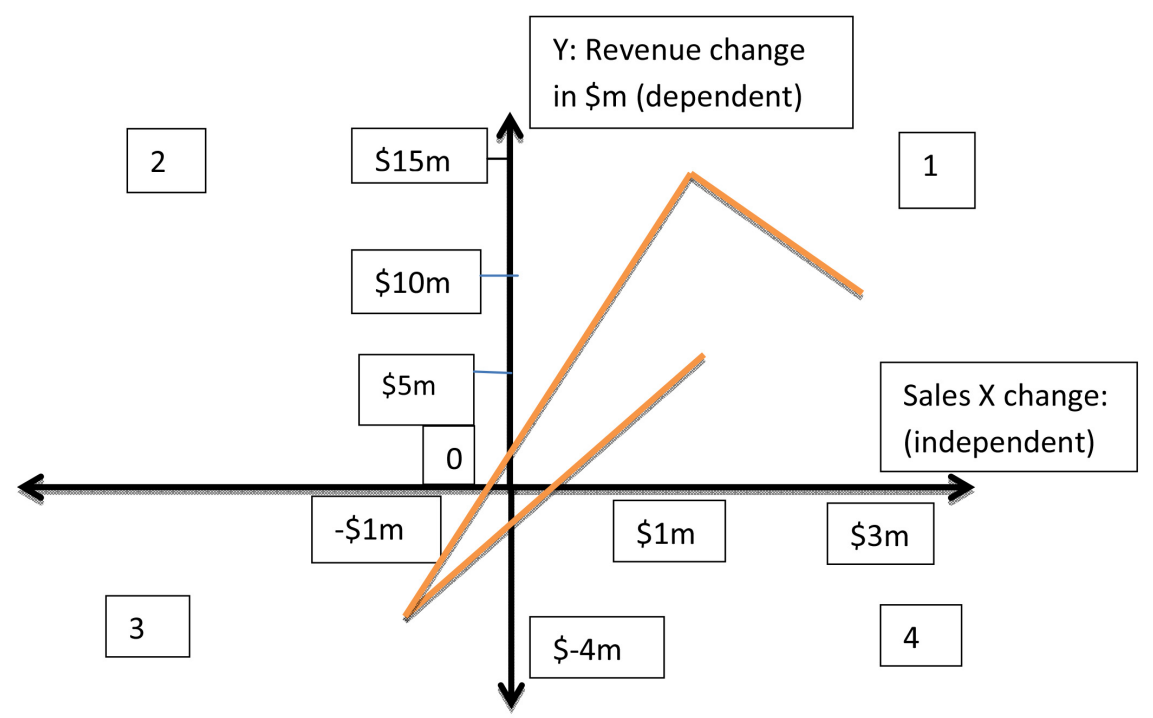

Figure 12. EL's Limit Cycle, 1988-1992.

In the next 4 years: in 1992-1993 sales rose by $0.58 \mathrm{~m}$ and revenue rose by $\$ 29.44$; in $1993-1994$ sales rose by $0.48 \mathrm{~m}$ and revenue rose by $\$ 3.72$; in 1994-1995 sales rose by $1.96 \mathrm{~m}$ and revenue increased by $\$ 31.54 \mathrm{~m}$; in 1995-1996 sales fell by $1.45 \mathrm{~m}$ and revenue fell by $\$ 9.6 \mathrm{~m}$. Thusvisits were $1,1,1,3$, i.e. a period 2, low order of chaos again (Figure 13).

The last period, 1996-2000, is shown below.

As shown (Figure 14), a rise in sales of $3.2 \mathrm{~m}$ metric tons in 1999-2000 brought-in an additional sum of $\$ 82 \mathrm{~m}^{48}$ (Q1)! In 1997-98, the company had a decrease in revenue of $\$ 22 \mathrm{~m}$ (period of steady sales) (Q3); and also in 1998-1999 $-\$ 6.7 \mathrm{~m}(\mathrm{Q} 4)$. So, two increases in sales (rises in fleet) brought two decreases in ${ }^{48}$ This stresses in the most dramatic way the influence of the uncontrolled price (freight rate); while sales increased, revenue fell. This indicates how important is forecasting! 


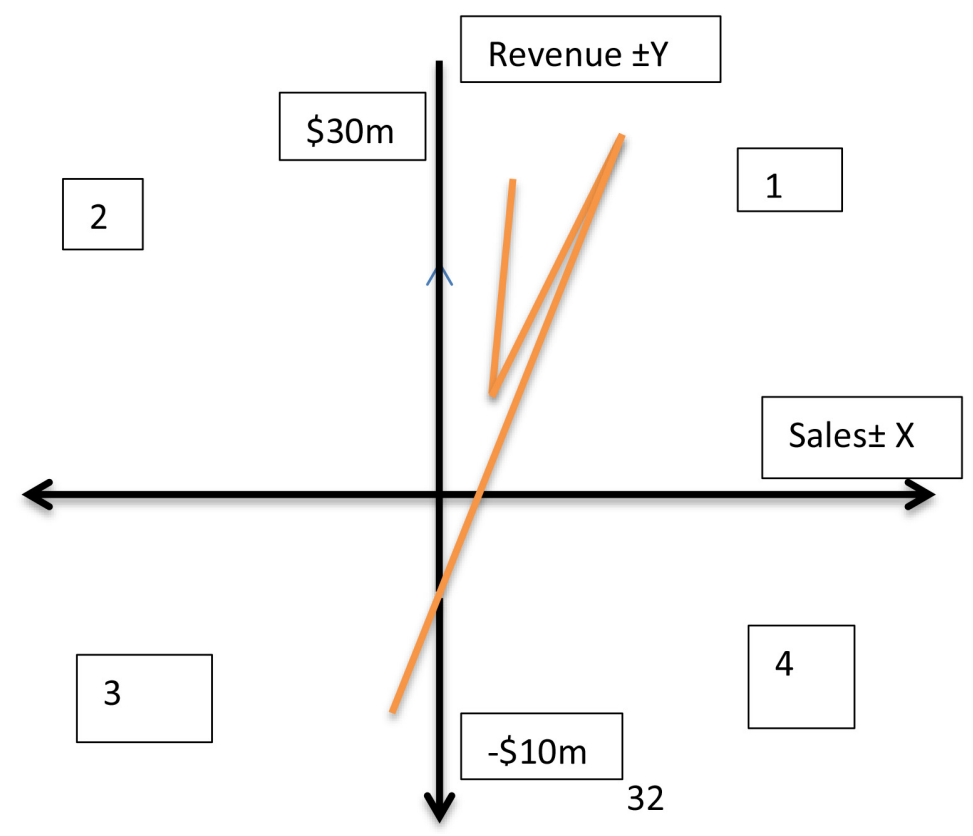

Figure 13. EL's Limit Cycle, 1992-1996. Source: as in Figure 12.

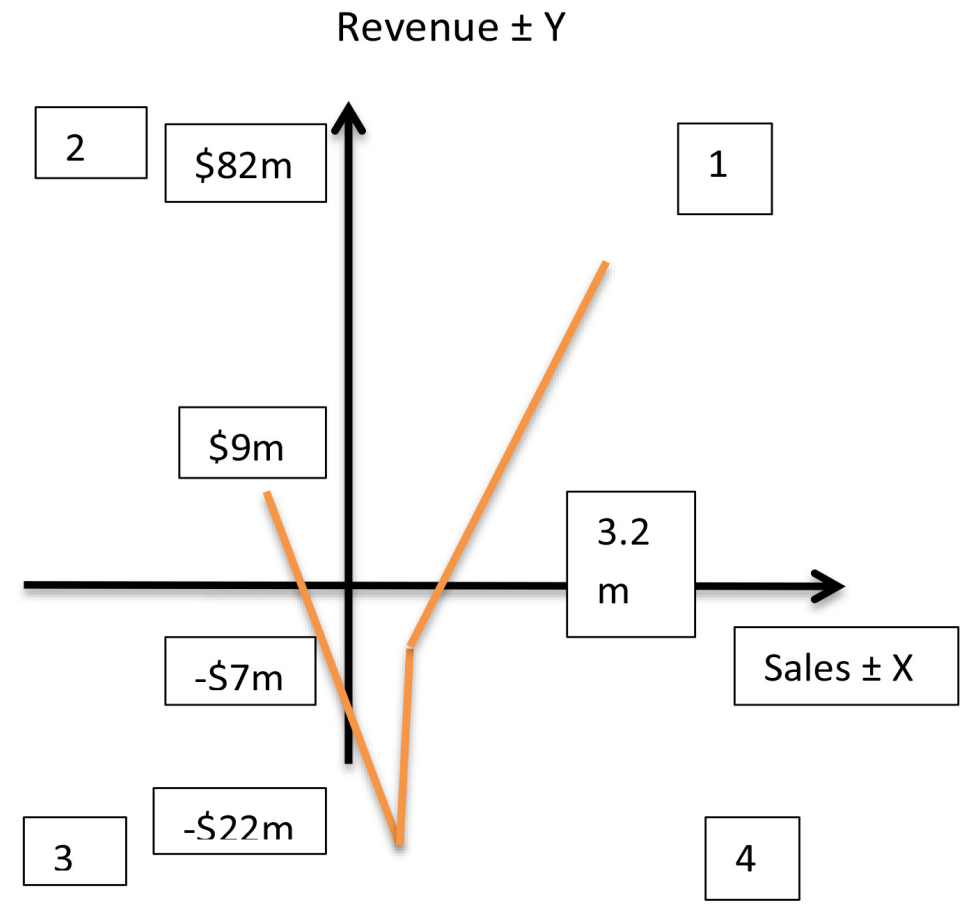

Figure 14. EL's Limit Cycle, 1996-2000. Source: as in Figure 12.

revenue due to market. Trajectories visited 2, 4, 4, and 1 quadrant. This reveals an 8-period limit cycle, or a high order chaos! Market thus paid $\$ 91 \mathrm{~m}$ additionally to $E L$, and it took back $\$ 29 \mathrm{~m}$. EL had not to allow this.

\section{Concluding Remarks}

Most probably EL was not pre-aware of the market conditions, at the time when 
its newly-built ships delivered. These deliveries succeeded so that EL to transport, in 1999, $3.2 \mathrm{~m}$ additional metric tons. EL showed a technology syndrome by ordering ships 3 years before their technology became obligatory by law.

This, we believe, led EL to have higher operating costs [24]. This differentiation is considered as providing a competitive advantage, but not for shipping, which is cost-based! Differentiation is the ability to provide unique and superior value to buyers(charterers) in terms of service quality, as well as other special features (= double hull; dedicated ballast water tanks; new-buildings). This policy is inherently more costly.

In shipping, a premium price cannot be asked for a superior quality, as in other industries! This justifies other Greek owners to buy larger than hitherto second-hand ships at a rather lower age and at rock bottom prices. Owners were stuck-in (locked-in) newly-buildings at the time when market was falling, offer their customers services of higher cost and perhaps were preferred by them, but they are paid only what market determined! Market decides who is paid and how much provided a ship is seaworthy, no matter new or old.

The four falls we saw $(1989 ; 1995 ; 1997 ; 1998)$ in EL's revenue had to be avoided. EL could either lay-up a number of ships (in 1989; 1995; 1996; 1997 and 1998) or resort to time-charters or plan better its new-buildings. This policy could have led EL to an 1-period limit cycle (low order of chaos) vis-à-vis 2-period it was in 1988-1996; while in the last period (1997-2000) company could be in period 4 (=medium order chaos), instead of being in period 8 (=high order chaos).

The cumulative revenue rises of EL between 1988 and 2000 was $\sim \$ 146 \mathrm{~m}$. If we add the amounts by which revenue fell during certain years, then potential revenue rise could reach $\$ 189 \mathrm{~m}$ (the forgone rise in revenue $=\$ 43 \mathrm{~m}$ ). We believe that EL's management did know EL's limit cycle. EL, in chaos language, had to avoid visits to quadrants 3 and 4 (i.e. falls in revenue, Y)! This recommends as one option a switch to a time-charter policy.

EL had also a "contest syndrome", i.e. to be better than the other owners though everyone was worse. Business is not a contest, but a profit-making enterprise! EL won the race by getting the gold medal, but it did not break the world record.

Given that three deaths occurred among the original owners, the young generation, which took over, we hope to change EL's mission from "supplying newly-built ships with latest technology independently from profits", to supply relatively young ships according to the intensity of demand and the level of freight rate. There is no free meal in businesses of a high order of chaos!

Paper's deficiency is that Chaos Theory is not well-known or even taught in business schools, with few exceptions. Matters change of course. People also dislike chaos as they consider chaos as a synonym of disorder. All we have been brought-up with the linear paradigm: the straight lines, which we call them curves; the normal distribution, which misleads investors; the variance as risk bell, which is not. A paradigm shift is needed. We never imagine a small effect to 
have a proportional greater result-life we believe is equally proportional. The $\%$ of action $=$ the $\%$ of the result. We never imagined that a small crack in the ballast tank of a diesel tanker will result in cutting the ship in two under severe weather conditions outside Italy!

\section{Conflicts of Interest}

The authors declare no conflicts of interest regarding the publication of this paper.

\section{References}

[1] Mandelbrot, B. (1983) The Fractal Geometry of Nature. Freeman \& Co., New York.

[2] Gleick, J. (1988) Chaos: Making a New Science. Cardinal, London.

[3] Jiang, S. (2015) More Evidence against the Random Walk Hypothesis. World Scientific, Singapore.

[4] Mandelbrot, B. and Hudson, R.L. (2006) The (Mis)behavior of Markets: A Fractal View of Financial Turbulence. Basic Books, New York.

[5] Priesmeyer, H.R. (1992) Organizations and Chaos: Defining the Methods of Nonlinear Management. Quorum Books, Westport.

[6] Morgan, G. (1986) Images of Organization. Sage, Thousand Oaks.

[7] Stacey, R.D. (1991) The Chaos Frontier, Oxford, Butterworth-Heinemann.

[8] Kellert, S.H. (1993) In the Wake of Chaos Unpredictable Order in Dynamic Systems, University of Chicago Press. https://doi.org/10.7208/chicago/9780226429823.001.0001

[9] Levy, D. (1994) Chaos Theory and Strategy: Theory and Applications and Management Implications. Strategic Management, 15, 167-178.

https://doi.org/10.1002/smj.4250151011

[10] Phelan, S.E. (1995) From Chaos to Complexity in Strategic Planning.

[11] Battram, A. (1998) Navigating Complexity: The Essential Guide to Complexity Theory in Business and Management. The Industrial Society, London.

[12] Ramnswamy, K. and Youngdahl, W. (2013) “Are Your Employees” Worst Enemy? http://www.strategy-business.com

[13] Goulielmos, A.M. (2018) Linear and Nonlinear Strategic Management: With Applications to Shipping. Modern Economy, 9, 97-124. https://doi.org/10.4236/me.2018.91007

[14] Goulielmos, A.M. (2018) Time and Equilibrium: Two Important but Invisible Concepts of Economics, with an Application to Shipping Industry. Modern Economy, 9, 536-561.

[15] Williams, G. (1997) Chaos Theory Tamed. Taylor and Francis, Abingdon-on-Thames.

[16] Goulielmos, A.M. (2018) The Nature of Economic Turbulence: The Power Destructing Economies, with Application to Shipping. Modern Economy, 9, 1023-1044.

[17] Mankiewicz, R. (2000) The Story of Mathematics. Cassell \& Co., London.

[18] Conway, J.H. (2014) Who's Who. A \& C Black, Bloomsbury Publ. plc, Oxford University Press, Oxford.

[19] Auerbach, D. (2016) The Theory of Everything and Then Some State.

[20] Robbins, S.P. and Coulter, M. (2018) Management 14E GE, with Contributors. 
Pearson, London.

[21] Stopford, M. (2009) Maritime Economics. 3rd Edition, Routledge, Abingdonon-Thames.

[22] Lloyd's 100A1 (1994) A Viewpoint of Gregory Hadjieleftheriadis of Eletson Corporation. Issue 2, 24-26.

[23] Lloyd's Shipping Economist (2001) Long-Term Planning Pays Off. June, 31-33.

[24] Goulielmos, A.M. and Plomaritou, P. (2009) A Review of Marketing for Tramp Shipping. International Journal of Shipping and Transport Logistics, 1, 119-155. https://doi.org/10.1504/IJSTL.2009.024492 


\section{Appendix 1}

Chaos period-1: when limit cycle trajectories visit the following quadrants, and in this order: 1111, 2222, 3333 and 4444. Chaos Period-2: when trajectories visit: 1112, 1222,2122, 2332, 3232, 3434, 4344, 1113, 1311, 2211,2333, 3233, 3443, $4411,1114,1313,2212,2422,3311,3444,4422,1121,1331,2221,2424$, $3313,4111,4424,1122,1333,2223,2442,3322,4114,4433,1131,1411,2224$, 2444, 3323, 4141, 4434, 1133, 1414, 2232, 3111, 3331, 4222, 4441,1141, 1441, $2233,3113,3332,4224,4242,1144,1444,2242,3131,3334,4242,4443,1211$, 2111, 2244, 3133, 3343, 4244, 1212, 2112, 2322, 3222, 3344, 4333, 1221, 2121, 2323, 3223, 3433, 4334. Chaos Period-4: when trajectories visit: 1423, 1243, $1342,1324,4123,4321,4231,4213,3241,3421,3142,3124,2134,2314,2413$, and 2431. Chaos Period-8: trajectories visit the remaining 155 quadrants sequences (not shown here for their number).

\section{Appendix 2: Eletson Company: Who Is Who ${ }^{49}$ ?}

EL is a major Greek tramp shipping company, established by four related sea captains, 53 years ago (1966). It eventually specialized in product tankers. EL applied specialization and economies of scale by going to every increasing individual sizes. Moreover, EL's company's policy is that of maximizing ownership, and almost exclusively, trade in spot market.

Table A1. EL business history, 1966-2015.

\begin{tabular}{|c|c|c|c|c|c|}
\hline Year & Fleet owned (dwt) (000) & Remarks & Year & Fleet owned (dwt) (000) & Remarks \\
\hline 1966 & established & & 2004 & 32 ships, $1.69 \mathrm{~m}$ & - \\
\hline 1969 & 16 (one tanker) & Crude oil & 2006 end & $\begin{array}{l}1.79 \text { m } 27 \text { ships; ordered } 6 \times \\
52(312) \text { chemical tankers }\end{array}$ & $\begin{array}{l}\text { Entry to chemical } \\
\text { tankers }\end{array}$ \\
\hline 1981 & 210 (7 product tankers) & Dirty oil products & 2007 & $\sim 320$ (4 Panamax) ordered & Product carriers \\
\hline $\begin{array}{l}1983 \text { (a shipbuilding } \\
\text { program) }\end{array}$ & 149.5 ordered (5) & Product carriers & 2008-mid & $1.79 \mathrm{~m}$ & \\
\hline $\begin{array}{c}1986 \\
\text { (technology } \\
\text { syndrome) }\end{array}$ & $\begin{array}{l}\text { Double-hull of } 46 \text { each, } \\
\text { ordered }\end{array}$ & $\begin{array}{c}3 \text { - } 4 \text { years before } \\
\text { USA law-oil pol- } \\
\text { lution } \\
\text { act-1990! }\end{array}$ & 2009 & $\begin{array}{l}\text { shipbuilding turned to LPGs } \\
\text { with } 35 \mathrm{k} \mathrm{cbm}\end{array}$ & LPG \\
\hline 1989 & 19 (12 d.h. \& 7 s.h.) ordered & Product carriers & 2011 & 3 LR1 tankers ordered & \\
\hline 1992 & $\begin{array}{l}1.17 \text { m }(450,15 \text { handy \& } 9 \\
\text { Panamax 720, p. c.d.h. })\end{array}$ & $\begin{array}{l}1993 \text { bond issue } \\
\$ 140 \text { m maturing } \\
2003\end{array}$ & 2013 & $\begin{array}{c}44.5 \mathrm{cbm} \text { ordered } \\
(1 \mathrm{LPG} 20.5 \mathrm{cbm} \& \\
2 \times 12 \mathrm{cbm}) .\end{array}$ & $\begin{array}{c}\text { Another bond issue } \\
\text { of } \$ 300 \mathrm{~m} \text { maturing } \\
2022\end{array}$ \\
\hline 1999 & $\begin{array}{l}152 \text { ( } 2 \text { used tankers } \\
\text { of } 76 \text { each) bought }\end{array}$ & $2^{\text {nd }}$ hand & 2014 May & $1.90 \mathrm{~m}$ & - \\
\hline 2000 & $\begin{array}{l}\sim 265 \text { (2 p.c. Panamax }+ \\
1 \text { Aframax } 105 \text { for the } 1^{\text {st }} \\
\text { time) ordered }\end{array}$ & $\begin{array}{c}15.14 \mathrm{~m} \\
\mathrm{mt} \text { transport of } \\
\text { oil products }\end{array}$ & $\begin{array}{c}\text { 2015, received } 12 \\
\text { cbm LPG/LEG, } 4 \\
\text { Aframa } \times(\sim 400 \mathrm{k}) \\
\text { and } 4 \times 12 \mathrm{cbm} .\end{array}$ & $\begin{array}{l}1.93 \mathrm{~m} \text { of } 29 \text { ships; } 15 \\
\text { chemical tankers } \\
\text { of } 305,940 \mathrm{cbm}\end{array}$ & Double hull \\
\hline 2001 & 211 ordered; $(2 \times 105.5)$ & $\begin{array}{l}\text { Owned } 1.13 \mathrm{~m} \text { in } \\
\text { Sept. } 2001\end{array}$ & $\begin{array}{l}\text { Deaths in 2001, 2003, } \\
\text { 2012, opened the } \\
\text { door to company's } \\
\text { 2nd generation }\end{array}$ & $\begin{array}{l}\text { EL got rid early of } \\
\text { single hull tankers }\end{array}$ & $\begin{array}{l}\text { Source: company's } \\
\text { booklet } 2001 \text { and } \\
\text { internet site }\end{array}$ \\
\hline
\end{tabular}

${ }^{49}$ From company's internet site. 